\title{
Realizing Public Values: Enhancement or Obstruction? Exploring Value Tensions and Coping Strategies in the Co-production of Social Care
}

\author{
AUTHORS \\ Corresponding author: \\ Sylke Jaspers, PhD Fellowship of the Research Foundation - Flanders \\ KU Leuven \\ Public Governance Institute \\ Parkstraat 45 P.O.Box 3609 \\ 3000 Leuven \\ Belgium \\ +3216376265 \\ Sylke.Jaspers@kuleuven.be \\ Trui Steen \\ KU Leuven, Public Governance Institute \\ Parkstraat 45 P.O.Box 3609 \\ 3000 Leuven \\ Belgium \\ +3216323276 \\ trui.steen@kuleuven.be
}

\section{FUNDING}

This work was supported by the Research Foundation - Flanders under Grant 11C2418N.

\section{PRE-PROOF VERSION}

\section{PUBLISHED ONLINE ON 22 AUGUST 2018}

doi: $10.1080 / 14719037.2018 .1508608$

\begin{abstract}
:
We examine the potential of co-production to enhance or obstruct the realization of public values by analyzing what value tensions co-producers experience and what coping strategies they follow. In-depth study of a social care initiative in Flanders shows that co-production enhances the realization of values relating to services delivered, relationships between public servants and citizens, and the democratic quality of the service delivery process. However, public servants and citizen co-producers experience tensions between values, such as efficiency, individual freedom of co-producers, reciprocity, and inclusion. In trying to deal with these value tensions public servants are found to follow a variety of coping strategies, whereas citizen co-producers tend to escalate tensions or avoid coping with them. The type of coping strategy followed, however, influences if and what values are ultimately represented in the service delivery process and its results.
\end{abstract}




\section{KEY WORDS}

co-production, public values, social care, value conflicts, coping strategies

\section{INTRODUCTION}

The growing elderly population and severe austerity measures taken in the health sector in Western countries have created a need for innovation in the delivery of care services. Co-production, where regular service producers collaborate with citizens to provide public services, is seen as a way to remodel public service delivery (De Vries, Bekkers, and Tummers 2015). Specifically for care services, the World Health Organization (WHO 2016, p.11) expects co-production to improve access, responsiveness to community needs and customer satisfaction, and result in a better relationship between individual care users and care providers.

Despite growing interest in co-production (e.g., Bovaird 2007; Alford 2009; Pestoff 2006; Thomsen and Jakobsen 2015; Meijer 2014; Brandsen, Steen, and Verschuere 2018), its fundamental nature and the effects claimed are still insufficiently understood (Meijer 2016). Building on the notion of public values as normative concepts that are used to give direction to public action and/or legitimize such action (Bozeman 2007; Witesman 2016), the literature acknowledges that public service providers frequently face value conflicts and tensions (Bozeman 2007; Schott 2015). Public servants try to balance 'traditional' governmental values - such as integrity, neutrality, legality, and impartiality - with 'businesslike' values - such as efficiency, innovation, responsiveness, and effectiveness (Hood 1991; de Graaf and van der Wal 2010). Additionally, public administration literature shows public servants adhere to coping strategies in order to deal with these tensions (Steenhuisen 2009; Schott 2015). Not only is it important to learn what values co-producers hope to uphold and what value tensions they experience, but we also need to understand how co-producers deal with such tensions: their coping behavior will influence whether the conflict is overcome or whether only part of the values at stake are represented in the service delivery process.

For example, initiatives in which elderly people co-deliver care to each other can increase responsiveness and participation, but may at the same time raise questions on inclusion, accountability, and quality. Is the target group both willing and able to co-produce, and do the less able elderly risk being excluded? Who can be held responsible for quality of services delivered when vulnerable elderly co-produce care for each other? These questions arise not only from an increasing attention to the potential dark side of co-production (Steen, Brandsen, and Verschuere 2018), but also from a consideration of how co-producers try to deal with this complexity. The existing body of co-production literature, however, lacks systematic evidence of its anticipated and unanticipated consequences (Verschuere, Brandsen, and Pestoff 2012). Therefore, our research question is: To what extent does co-production in social care either enhance or obstruct the realization of public values in the service delivery process and outcome? We studied the potential of co-production for realizing public values by looking into (1) what public values are experienced by co-producing actors as conflicting and (2) how actors cope with public value tensions. 
We conducted an exploratory study of the value conflicts encountered by individual co-producers and the impact of their coping strategies on the realization of public values, specifically in the coproduction of a social care service. Below, we will first discuss concepts and theories from the literature on public values, value tensions, and coping strategies. Second, we analyze a coproduction initiative set in a small municipality in Flanders. In this initiative, here given the fictional name of 'Connected Care', local government is experimenting with co-production with the aim of de-isolating vulnerable elderly.

\section{Co-Production of Public Values}

We first discuss our theory on co-realizing public values so as to get an insight into public values and their connection to co-production. Second, we discuss the literature on public value tensions and what this implies for co-production and the various actors involved. Third, we turn to the literature on coping with value tensions. The theoretical framework provides a basis for our empirical exploratory research.

\subsection{Co-production as a means for realizing Public Values}

Public values are much discussed in public administration literature (Beck Jørgensen 2006; Beck Jørgensen and Bozeman 2007; Bovens, 't Hart, and van Twist 2007; Rutgers 2008; de Graaf and Paanakker 2014; de Graaf, Huberts, and Smulders 2016). Public values indicate 'the procedural ethics in producing public services and [...] outcomes made possible by producing public services' (Bryson et al. 2017, 451). As mentioned in the introduction, co-production is seen as a way to remodel public service delivery and thereby improving the realization of public values.

Citizen co-producers and public servants have significant roles to play in co-production, and hold expectations of this collaboration. In co-production, service users become actively involved in the delivery of the services. Public servants, in turn, step beyond their traditional role as service providers by taking the responsibility for shaping an institutional context for co-production, and motivating and enabling citizen co-producers (Steen and Tuurnas 2018; Van Eijk 2017).Coproduction provides the opportunity for increasing efficiency and quality of service delivery through better use of time, efforts, and resources (knowledge, expertise) of both public servants and users. This may contribute to greater user satisfaction and better targeting of services (Pestoff 2006). Co-production is expected to enhance the relationship between citizens and public servants and to become a mechanism for increasing responsiveness and tailoring services to personal needs (Vanleene, Voets, and Verschuere 2017). Finally, co-production is expected to enhance democratization, since it is seen as a source of citizen empowerment (Fledderus 2015). Specifically for social care services, Ross, Needham and Carr (2013) define a set of values that care coproduction should attain: equality, diversity, accessibility, and reciprocity. The principle of reciprocity, 'defined as ensuring that people receive something back for putting something in, and building on people's desire to feel needed and valued' (p.13-14) is seen as a key concept in care co-production. Studies of healthcare services show that in order to realize the public values mentioned above many governments are searching for ways to co-produce care services (e.g., WHO 2016) - including, co-produced assisted living technologies (Batalden et al. 2015), 
collaborative health care (Wherton et al. 2015) or social care (Needham \& Carr, 2009; Ross et al. 2013).

From this we derive three clusters of public values desired in the social care sector and potentially realized through co-production: service delivery (e.g., efficiency, process or outcome effectiveness, quality of the services, user satisfaction); relationship between public professional or organization and citizens/service users (e.g., mutual learning, trust, accountability, responsiveness, transparency); and democratic quality of the service delivery process (e.g., participation, empowerment, equity, social capital, inclusion, diversity, reciprocity) (see also Vanleene, Voets, and Verschuere 2015).

Studies show that citizen co-producers and public servants may have different expectations of co-production (e.g., Van Eijk and Steen 2014; Alford and Yates 2015). Of course, what exactly these expectations are varies, since they are experienced at the individual level. Central to our study is the question whether the value tensions public servants experience when delivering services may also be experienced by co-producers involved in public service delivery and thus may hinder the realization of the public values so desired from co-production.

\subsection{Value Tensions}

A recurrent issue in Public Administration literature is that of public servants experiencing conflicts between public values, having to balance values such as integrity, neutrality, legality, impartiality, efficiency, innovation, responsiveness, and effectiveness (Hood 1991; de Graaf and van der Wal 2010; van der Wal, de Graaf, and Lawton 2011; de Graaf, Huberts, and Smulders 2016; O'Kelly and Dubnick 2006). Despite some recent empirical studies (e.g. Maynard-Moody and Musheno 2003; de Graaf and Paanakker, 2014; Schott 2015; Schott, Van Kleef, and Steen 2015), overall, empirical evidence on conflicting values is still rare (de Graaf, Huberts, and Smulders 2016).

Co-production offers a new context for upholding public values (cf. Alford 2014, 2016; Osborne, Radnor, and Strokosch 2016; Farr 2016), which might either add to or resolve some of the public value tensions. For example, employing users' resources may increase efficiency while safeguarding effectiveness. Introducing peer workers and empowering clients may reduce the cost of service delivery while benefiting other values such as reciprocity or effectiveness (Ross et al. 2013). However, co-production may also lead to 'de-construction' of values (Williams, Kang, and Johnson 2016). Co-production may strengthen insider/outsider dynamics if access is only guaranteed for specific social groups (Brandsen and Helderman 2012). Coproduction can be 'time-consuming' (Neshkova and Guo 2012). It may result in user dissatisfaction because of a failure to fulfil high expectations (Gebuaer, Füller, and Pezzei 2013), and in a lack of impact as perceived by users or citizens (Buckwalter 2014).

Although value tensions experienced by citizen co-producers have not been studied yet, we expect these tensions to differ from the tensions experienced by public servants involved in coproduction. Citizen co-producers become producers of the service, while remaining users of the same service. Therefore we may expect tensions to arise around them becoming service producers - i.e., putting in efforts and contributing to the production of services including public values (Alford 2002) - while at the same time remaining service users - mostly concerned with a self-centered effectiveness, or achieving private value (Alford and Yates 2015). 
Recognizing that co-producers may experience value tensions we now turn to another strand of literature, i.e., that of psychology and organizational behavior, where research focuses on how value tensions are coped with. The concept of 'coping strategy' provides a conceptual lens to study how conflicting values are dealt with by citizens and public servants engaged in coproduction. Ultimately, their coping behavior will affect the outcome of co-production processes, because it influences whether public values are destroyed or enhanced.

\subsection{Coping Strategies for dealing with value tensions}

In the literature public servants are found not only to experience public value tensions, but also to follow coping strategies in order to deal with these (de Graaf and Paanakker 2014; Lipsky 1980). For traditional public service production Tummers et al. (2015) found that public servants confronted with tensions related to public service delivery do any of three things: they confront the client, they avoid interaction with the client, or they are responsive to the client's needs. In the literature the concepts of coping behavior and coping strategies are used to investigate how tensions between competing values and demands are managed (e.g., de Graaf et al. 2016; Lipsky 1980; Steenhuisen and Van Eeten 2013; Thacher and Rein 2004; Stewart 2006). Steenhuisen $(2009,20)$ defines coping as 'a response to competing values that takes form in the actions and decisions'.

Coping strategies are often studied by considering the ethical standards applied in dilemma situations (e.g., Sims and Keon 1999, Loyens and Maesschalck 2008). Bartels (2013), however, argues that rather than people rationally applying strategies, behavioral patterns dynamically emerge in the relationship between citizens and public professionals. This is supported by Lukes (1996), who shows that trade-offs (whose archetype is cost-benefit analyses) cannot explain all choices we make. According to Thacher and Rein (2004) this is due to actors not treating conflicting values as commensurable.

Knowledge on how value tensions are dealt with in collaborations between different actors is scarce (van Gestel et al. 2008), but the existing literature provides us with a variety of coping strategies (e.g., Thacher and Rein 2004; Stewart 2006; Steenhuisen 2009; van der Wal, de Graaf, and Lawton 2011; de Graaf, Huberts, and Smulders 2016). Stewart (2006) discusses three coping strategies also named by Thatcher and Rein (2004): firewalls, cycling, and casuistry, and adds three more strategies to this list: bias, hybridization, and incrementalism. From the work of Tetlock (2000) and de Graaf, Huberts and Smulders (2016) we derive a seventh coping strategy, 'escalating'. This body of literature yields the following list of strategies:

- 'bias', or a specific type of trade-off: giving preference to values consistent with a dominant discourse, or larger values set at the expense of other conflicting values;

- 'building firewalls': appointing different institutions, administrative units, or individual positions aimed at certain public values in order to distribute responsibility for pursuing the competing values;

- 'cycling': paying sequential attention to competing values;

- 'casuistry': making decisions for each particular value conflict based on experiences in previous cases, and in doing so crafting a customized response based on those examples;

- 'hybridization': seeking coexistence between values by sustaining distinct policies or implementations that pursue these competing values; 
- 'incrementalism': slowly putting more and more emphasis on one particular value;

- 'escalation': elevating questions about competing values to a higher administrative or legislative authority.

Different coping strategies, however, lead to different public values being realized. From the above list it becomes clear that some of the coping strategies may enable the realization of two conflicting public values (e.g., building firewalls, cycling, and hybridization). Other coping strategies lead to the realization of one value and consequently the deconstruction of the conflicting values (e.g., biasing, casuistry, and incrementalism). Finally, 'escalation' refers to the question of accountability that arises in the context of co-production, yet leaves it unclear to what extent this strategy results in public values being realized/upheld.

So far, citizens' coping strategies for dealing with value tensions have not yet been the subject of studies. Nevertheless, we do find some studies on coping in stressful situations related to policy changes (e.g., Bidani et al. 2012). Habibov and Afandi (2017), for example, recently studied people coping with the impact of the financial crisis. Although these studies cannot provide us with a framework for studying citizens' coping strategies in the face of value tensions, they do support the claim that citizens understand and deliberate on these problems in daily life (Gustafsson and Lidskog 2012). Because in co-production citizens become producers of the service, we will use the same theoretical and conceptual framework for studying citizen co-producers' coping strategies as we do for the public servants. However, we do expect a difference in coping with value tensions, because of the different roles of these two groups. For example, we expect citizens coping with value tensions to follow strategies in which they bias the values related to achieving personal benefits for themselves, since citizen co-producers are involved in co-production because of their specific motivation, and according to their ability, self-efficacy, and satisfaction with the service (Alford 2002, 2009; Alford and Yates 2015).

In sum, coping strategies provide a means to understand the cognitive mechanisms for dealing with tension situations, and enhancing or obstructing public values in the service delivery process. The coping strategies discussed differ conceptually. Some of the strategies discussed in this section, such as creating firewalls, belong more to the organizational level; others, such as bias, more to a personal coping level (de Graaf, Huberts \& Smulders 2016). Finally, de Graaf, Huberts and Smulders $(2016,1110)$ point out that this means "that multiple coping strategies might be used in response to a single value conflict". Additionally, in co-production people are placed in a context of collaboration, so their interaction may influence their experience (e.g. Osborne, Radnor and Strokosch, 2016) and thus their individual coping.

We now turn to an exploratory empirical case study in the social care sector. We studied the potential of the co-production initiative for enhancing and obstructing public values in one case in the social care sector by analyzing the individual co-producers' expectations about public values, to see whether they experience value tensions and what these are, and how they cope with them.

\section{MeTHODS}

\subsection{Case Selection, Population Sampling and Data Collection}

Several researchers discuss co-production in healthcare services (e.g., Dunston et al. 2009; Amery 2014; Loeffler et al. 2013) and the improved partnership between patients and clinicians 
(e.g., Braddock 2010; Carman et al. 2013). In comparison, far fewer scholars focus on coproduction of social care (e.g., Needham and Carr 2009; Ross et al. 2013). While co-production is not a new delivery mechanism for social care services, it is gaining more popularity because it affirms and supports an active and productive role for service users (Needham and Carr 2009).

We have studied the 'Connected Care' initiative, which aims to de-isolate vulnerable elderly and is situated in a small city in Flanders. Informal social care is organized by the users themselves, at the invitation of a local public servant. A second objective of Connected Care is to empower the service users, and minimize the financial burden for both local government and persons in need.

The concept of Connected Care is to connect demand and supply among the elderly. This is operationalized through publishing participants' direct demands and offers in a monthly magazine and on a website, meeting each other in monthly meetings or weekly workshops, or drinking coffee together in the meeting rooms at local care centres.

We first created a 'snapshot' of all actors involved in the Connected Care initiative and selected the respondents (see Table 1). The two project coordinators are the initiators of the project, and 80 citizens are involved in the co-production. Connected Care identifies itself as a network of people, and each inhabitant of the municipality, irrespective of age (although the initiative primarily targets elderly people), origin, gender, or education may join. The youngest participant is 39 years old $\left({ }^{\circ} 1978\right)$, the oldest $94\left({ }^{\circ} 1923\right)$. Connected Care has a steering committee, which consists of the public servant (R9), a volunteer project coordinator (R10), and four participants (R4, 7, 8, and 11). These latter four are elderly persons who, next to being active participants of the initiative, are also on the steering committee. This committee is tasked with coordinating and expanding or deepening the network, in direct interaction with the other participants. The volunteer has a professional background as a social worker. She helped setting up Connected Care and afterwards decided to remain as a volunteer. Because both the public servant and the volunteer take up coordinating tasks in the project, we will refer to them as project coordinators.

\section{Table 1. Population of the Connected Care case}

$<<$ include table 1 here $>>$

We conducted semi-structured in-depth interviews with the public servant and the volunteer involved, the four citizen co-producers taking part in the coordinating meetings, and 11 other citizen co-producers ${ }^{1}$ (see Appendix, Table A). The sample was chosen in consultation with the public servant, with the aim of identifying a wide range of perspectives rather than numerical representativity. We consulted the public servant about contacting respondents of varying age, gender, and intensity of participation (see Appendix, Table B). Although we tried to select our respondents to reflect the variety of perspectives, we are aware that there may be a certain bias.

\footnotetext{
${ }^{1}$ One of the interviews conducted was a joint interview with respondents 16 and 17 , at the request of one of them.
} 
Our study was restricted to a limited group of respondents involved in one co-production case in the social care sector. The exploratory nature of this study means that the value tensions experienced by the actors studied and the coping strategies they follow, are case specific. An analysis of another co-production initiative in social care, which involved a technological innovation, identified other tensions experienced by the co-producers, involving values such as privacy, inclusiveness, and equity (XXXX, 2018). Thus, with this exploratory study we aim to gain insight into the potential of co-production for enhancing or obstructing the realization of public values in service delivery, rather than drawing conclusions on what specific values are enhanced or obstructed.

\subsection{Data Analysis}

A thorough analysis of the interviews was carried out by means of the NVivo software. Codes were created on the basis of the theoretical framework - referring to distinct public values and coping strategies - and applied to the data on the basis of phases of open and axial coding (cf. Strauss and Corbin 2008). The qualitative analysis followed an iterative, open process. The open coding phase enabled us to include values and coping strategies not mentioned in the literature but identified in the empirical data, such as individual freedom, reciprocity, and deferred coping. In the coding process we were careful in interpreting these, and in connecting them to the corresponding public values and coping strategies as defined in our theory (see also the empirical analysis of public values by Beck Jørgensen 2006, and the empirical analysis of value tensions by de Graaf and Paanakker 2014). Table 2 shows the final coding list.

\section{Table 2. Codes and subcodes for the interview analysis}

$<<$ include table 2 here $>>$

As pointed out in the theoretical discussion we assumed the expectations, tensions experienced, and coping strategies followed by regular service providers to be different from those experienced by citizen co-producers. For this reason we analyzed the data ${ }^{2}$ separately for the project coordinators ( 2 respondents), the citizen co-producers (11 respondents), and - since they have additional responsibilities - the citizens active in the steering committee (4 respondents).

\section{RESULTS}

\subsection{Co-producers' Expectations Towards Upholding Public Values}

\subsection{1 $\quad$ Services delivered}

The various actors involved in the case have varying expectations about services delivered. The project coordinators claimed that satisfaction of the citizen co-producers indicated the project's success: 'it is important that people feel involved because it gives a good feeling' (R10, also 4, $8^{3}$ ).

\footnotetext{
${ }^{2}$ The quotes presented in the results section were translated by XXX.

${ }^{3}$ The number identifies the respondent (see the Appendix for details on the respondents).
} 
Citizen co-producers claimed to feel satisfied when the project was effective, and expected Connected Care to help them become de-isolated $(\mathrm{R} 4,5)$ and to be considerate of their needs (R5, 16). Furthermore, the project coordinators stressed the importance of effectiveness and so lent flexibility to the process. While connecting demand and supply of the elderly is still relevant, organizing joint meetings was felt far more effective in de-isolating participants and improving their social capital $(\mathrm{R} 1,9)$, which resulted in an increased focus on these meetings.

\subsubsection{Relationship between professional and citizen}

Citizen co-producers expect the initiative to be considerate of their needs (R1, 2, 13, 15). Similarly, the project coordinators attach great importance to being responsive, 'Connected Care is about growth and being responsive to people's needs and not to what we want' (R9, also 10), and to being considerate of and recognizing participants' capacities as assets (R9), which is also an expectation of the citizen co-producers $(\mathrm{R} 1,2,5)$. The coordinators expect the participants to be responsive to each other's needs: 'we just offer a modest framework but they have to execute the service' (R9). Citizen co-producers hope to be able to trust the steering committee and project coordinators, and hold them accountable (R5, 16). Finally, the citizen co-producers value individual freedom (cf. a public value mentioned by, e.g., Tetlock 1986, Cordelli 2013, Moore 2014). This entails the choice of when, how, and how much to co-produce: 'there should be no obligations, otherwise I don 't want to be involved' (R7, also 4, 7, 8, 15). For the public servant this value then becomes important as a means to ensure inclusion 'everyone can participate in their own manner' (R9).

\subsubsection{Democratic quality of the service delivery process}

Both project coordinators and citizen co-producers wish to co-create empowerment and social capital (R2, 3, 5, 7, 9, 10, 13, 14, 16, 17). The project coordinators aim to increase participation 'the project needs to operate [...] through the active participation of the participants' (R9), inclusion, and diversity, which is related to inviting people from all ages, empowerment, and equality -'we need to get rid of the positions of public professional and clients [...]. It is important [to] empower people in Connected Care to help others, who then also become professionals' (R9). The project coordinators value reciprocity, which they understand as offering and receiving aid to and from each other according to capacities and needs (R10, 9). For the citizen co-producers, social capital (especially bonding with other local elderly) is a desired outcome of co-production, which they see as a means towards receiving private value such as 'going to the shop, doing household tasks, being busy doing something' (R3) or 'to live as long as possible at home' (R2). The citizens also value participation, inclusion, and reciprocity $(\mathrm{R} 5,7,13,16)$.

\subsection{Public Value Tensions Experienced in Co-production}

Many of the above mentioned values are expressed by the respondents as not only expectations held, but as actually being attained in the Connected Care initiative. Almost all respondents claim to have gained social capital $(\mathrm{R} 2,3,5,13,14,16,17)$ : they express the results of participation in the process as developing a social support system (cf. bonding social capital: see Szreter and Woolcock 2004). Additionally, they all feel that the elderly are less isolated and that co-producers are satisfied about the initiative. However, some values seem difficult to realize. Even considering 
local demographics the number of male participants is small, which raises questions on inclusion. Additionally, respondents from both the project coordinators and citizen co-producers groups feel that the opportunity for an individual to create social capital decreases when more participants join, because contacts then become more superficial. Furthermore, respondents raise questions on the effectiveness of the method to link care demand and supply, while others feel that a great need for organizing activities during weekends is not addressed.

To better understand the co-production initiative's potential for realizing public values, we next discuss how respondents experience tensions between values. We analyzed the data for the project coordinators, the members of the steering committee, and the citizen co-producers separately. This enabled us to investigate whether regular public servants were still experiencing value tensions when involved in co-production, and if citizen co-producers, as 'new' actors involved in the service delivery process, experienced value tensions and were co-creating public values.

\subsubsection{Project coordinators}

Most value tensions experiences by project coordinators involve either efficiency or individual freedom (see Figure 1). In their role of public managers they see efficiency as an ingrained value to public service delivery. In contrast, starting from their role as enabling the co-production, it is rather individual freedom that they see as a value necessary to involve service users.

\section{Figure 1: Project coordinators' value tensions ${ }^{4}$}

$<<$ include figure 1 here $>>$

Efficiency is valued by the project coordinators mainly because of financial limitations. This economic reality leads to tensions if confronted with the values of effectiveness, inclusion, and sustainability. For example, efficiency is felt to conflict with inclusion as the project coordinators experience that in order to involve the structurally most isolated elderly, more time and effort is needed: ' a lot of effort is needed to involve them [...] the most isolated elderly need a different approach. There are, however, no resources to get them here and to keep them here' (R9).

In the project coordinators' opinion the individual freedom for the participants to choose when, what, and how much to co-produce limits the effectiveness of the project, as well as the democratic quality of the service. The freedom of the participants results in many of them not showing up at activities, which limits their integration in the group $(\mathrm{R} 9,10)$. The project coordinators find that individual freedom conflicts with one of the main goals of the project, creating social capital for the participants: 'we do not want friends sitting together when there is a group meeting because

\footnotetext{
${ }^{4}$ The figures are added as a roadmap through the section, with the aim of adding some structure. However, they illustrate the results of a single exploratory case study and do not claim to provide a wider overview of what value tensions exist or do not exist in co-production processes.
} 
we want them to make contact with other people, so that they [...] include other people' (R10, also 9).

Furthermore, the project coordinators feel that participants' individual freedom is in conflict with reciprocity. Connected Care has as one of its key values that of reciprocity, while taking into account the capacities and needs of the participants: in return for receiving aid, participants should 'pay it forward', return the favor, or simply say thank you. The project coordinators state that very few of the 80 participants are prepared to offer support when other participants need urgent or apparent assistance, even if their capacities allow them to. Thus, the freedom of participants to choose in how far they get involved limits reciprocity: 'People always need a choice to say yes or no' (R9) but 'it is always the same people putting in an effort' (R10).

Connected Care takes the members' abilities and interests as a starting point. However, accountability remains with the project coordinators and this results in the public coordinators not always trusting the citizen co-producers: 'I expected in advance that it would be necessary for me to keep an eye on them while they co-produce the activity' (R10).

\subsubsection{Citizen co-producers}

The interview data indicate that citizen co-producers experience value tensions different from those experienced by the project coordinators. Values often felt to conflict with other values are inclusion, individual freedom, and reciprocity (see Figure 2). Individual freedom and reciprocity are clear prerequisites for individuals to participate, inclusion is perceived as much more normative.

\section{Figure 2: Citizen co-producers' value tensions}

$<<$ include figure 2 here $>>$

Citizen co-producers experience that inclusion or welcoming everyone to participate, which they do value normatively, may limit the realization of social capital, quality of the service, efficiency and reciprocity. The more people join, the harder it becomes for the citizen coproducers to get to know everyone, and thus ensure social capital as a democratic value in the process. In a discussion between two respondents this experience becomes clear:

- I do not think we should open up more, we should invest in what we have and make sure to strengthen the relationship between the people who are participating (R16).

- I have the same idea, there are already enough of us, but of course, if someone wants to join we cannot tell them they can't (R17).

Another example, is the tension between inclusion and reciprocity. In line with the value of inclusion, the activities are free for participants. However, participants who frequently depend on others for transport find it hard to offer reciprocity since they feel they have "nothing to give back' (R17, also 3, 11, 12), while the participants providing transport risk feeling they do not receive the value of reciprocity since 'they know how much they pay at the gas station' (R16).

The citizen co-producers' individual freedom is crucial for their participation, but at times this is experienced as conflicting with other values such as social capital (R1, 5, 14, 16) and 
sustainable reciprocity. For example, the individual freedom that participants have is, while perceived as welcoming, seen as an insecurity for the future, both as regards the sustainability of the initiative -'people do not want to be bound to something, especially not young people. But you do need people to keep the organization going' (R2, also 7) - and the sustainability of the care that citizen co-producers wish to receive in the future from other participants according to the principle of reciprocity.

\subsection{3 $\quad$ Steering committee}

The members of the Connected Care steering committee also experience value tensions. The tensions observed in this exploratory study involve especially efficiency and individual freedom (see Figure 3). These are the same two central values as experienced by the project coordinators, but the values they are conflict with are different and linked more to the concerns of the citizen coproducers. Thus, the members of the steering committee experience a mix of tensions linked to both the role of project coordinator and that of citizen co-producer.

\section{Figure 3: Steering Committee's value tensions}

$<<$ include figure 3 here $>>$

First, like the project coordinators, the members of the steering committee experience a tension between efficiency and effectiveness. They question whether the supply-and-demand method is the most effective for achieving the desired outcome values, although it seems to be the most efficient (R4). Second, there is the perceived tension between efficiency and trust. Although the committee members acknowledge the need for efficiency, they do not accept decisions being made by the project coordinators without previous consultation or communication with the board: 'I think they [the project coordinators] at least need to warn you and keep you up to date'(R8).

Like both project coordinators and citizens, the committee members are concerned about the effectiveness of the project. They experience a conflict between individual freedom and creating social capital: when people form groups this excludes both existing and new participants, thus limiting the creation of social capital $(\mathrm{R} 4,8)$. Reciprocity conflicts with individual freedom $(\mathrm{R} 4,7)$, as also experienced by the citizen co-producers: 'the oldest person is 90, you do not expect her to get up and clean tables, but from the younger people, you expect them to do something. [...] but nobody is obligated to do something here, so that is the end of $i t^{\prime}(\mathrm{R} 4)$.

\subsection{Co-producers' Coping Strategies when Confronted with Value Tensions}

In the theoretical section we identified a variety of coping strategies and argued that the strategies followed affect the potential for realizing public values. Therefore we asked our respondents about their coping strategies.

\subsubsection{Project coordinators}

Not only were all seven coping strategies distinguished in the literature identified in the interviews with the project coordinators, we also found one additional strategy. We refer to this as 'deferred 
coping': people express their hope to use a specific coping strategy in the future, but for the time being postpone dealing with the value tension at hand. For example, increased co-production (i.e., transferring more responsibility to the participants) could be the way to balance out the tension between efficiency and effectiveness. The desired coping strategy here is 'hybridization': 'we need participants who can take over from other people, we need members that can do part of our tasks. But the big problem is: we need more time to put energy in this' (R9). However, for the time being the project coordinator feels this is not possible, since she assumes that citizen co-producers need extra supervision and training to take over some or all of these tasks (R9).

Next to deferred coping, we find examples of project coordinators following the strategies of biasing, casuistry, or incrementalism. These strategies result in only one value being upheld. We illustrate these coping strategies by the tension between individual freedom and effectiveness of the project goals (creating bonding social capital, empowerment, de-isolation, inclusion). These two values conflict when general activities take place in the project, and the issue arises when the coordinators want to decide whether participants may choose where to sit, or if there will be fixed seating (which changes each meeting), intended to facilitate integration of and contacts between participants. In this case, the coordinator preferred fixed seating because it means that the project goals are reached and democratic quality of the service delivery is realized, whereas individual freedom - letting participants decide where to sit - would hinder the realization of these values.

- Applying a bias strategy, project coordinators show a preference for some values according to a dominant value set at the expense of other values: 'my role is to guard these values, to guard co-creation, democratic decision making, inclusion, believing in the abilities of the elderly, in openness, in trust, in diversity' (R9). The example of biasing most discussed $(\mathrm{R} 9,10)$ involved the values of individual freedom and social capital: ' $I$ prefer the value of social capital [...] because it's aimed at getting to know each other and inclusion. I am aware that because of this some people choose not to come to the upcoming general meeting. But if we don't tackle exclusion this project may as well be stopped in my opinion' (R9).

- With a casuistry strategy, decisions are made on how to deal with each particular value conflict on the basis of earlier experiences: having learnt from previous general activities that because of individual freedom there were citizens who did not receive value of social capital or inclusion (R9).

- A strategy of incrementalism is found when citizens express their dissatisfaction with this limitation of their individual freedom, and the public servant expresses the importance of the value to the participants: 'we will keep explaining to them why we opt for fixed seats in the general meetings, I will invite them all in order to explain the reasoning behind this decision' (R9). By doing so, the public servant slowly puts more and more emphasis on one value.

Finally, in this case study different values around which a tension is experienced were found to survive the value conflict if project coordinators stuck to 'building firewalls' and 'cycling'. 
- The project coordinators build firewalls as to which value is realized where. In the general meetings inclusion is insured through the realization of social capital. In the supply-anddemand part of the project, inclusion is guaranteed through the realization of individual freedom (R9).

- Because of efficiency considerations the coordinators often cycle between different value creating activities, and so give sequential attention to these values, by organizing many different activities: some where they realize social capital, other where they realize empowerment the participants (by letting them rediscover their capacities and talents and putting them to use) and giving them more accountability (e.g., brainstorming about input for new activities etc.).

In sum, the project coordinators follow a variety of coping strategies, probably because of the flexibility they have in designing and implementing the project. More importantly, following all coping strategies ensures that although value creation is obstructed through some coping strategies and deferred coping, it is enhanced through other strategies.

\subsubsection{Citizen co-producers}

Generally, in this exploratory case study citizen co-producers confronted with tensions tended to avoid the conflict - a new coping strategy found in addition to the list of coping strategies discussed in the theoretical part, and which we will call 'avoidance'. Also, conflicts are avoided by escalating the problem to the project coordinators or the steering committee. Studies of citizens' behavior in participatory practices help explain why they avoid dealing with value tensions. Lehoux, Daudelin and Abelson (2012) show that citizens often lack the capacity to react on the spot and may get frustrated by this, or they do not see how their competencies are relevant to the tasks at hand. They may thus opt for escalating or avoiding conflicts because they do not possess the capacity (voice) to cope with the value tension at hand in another way.

Citizens escalated dealing with tensions and expect the committee and the coordinators to take over because of (1) high pressure on the individual co-producers - 'I already have enough people to take care of' (R17) -, and (2) accountability - 'if there is a conflict [the project coordinators] will help with the decision' (R1, also 16, 17). This may be partly explained by tensions that often arise from working with others, so that the co-producers feel in need of a neutral referee to handle these issues. Through escalation, citizen co-producers place the responsibility for coping with value tensions with the project coordinators and members of the steering committee. In line with the concern raised by Steen, Brandsen and Verschuere (2018) about ensuring supervision of and accountability for the quality of public services being co-produced, escalation indicates a need for further study of the impact of co-production on accountability and responsibility for upholding public values, for example to investigate if the accountability stays with public servants or is shared with co-producers.

Some citizen co-producers avoid dealing with tensions by considering whether to drop-out. For example, because of a tension between individual freedom and social capital: 'if I have to do something because I have to, I will quit' (R1, also 5). Respondents avoid receiving assistance because of the value of reciprocity: 'I rather not receive assistance because I have nothing to offer in return' (R6, also 3, 11, 12). 
Furthermore, citizen co-producers follow coping strategies such as biasing, casuistry, and incrementalism, which lead to the realization of only one value. One respondent claimed that she learned from previous experiences how to cope with certain conflicts (or casuistry): she learned to ask for assistance from the public servant when she feels too much pressure (R16). On the tension between individual freedom and social capital, experienced by many during the general meetings with fixed seating, R14 explained that 'In the beginning I felt that my freedom was limited, but then I asked why they did this. When you know why you start understanding and accepting. Now I try to explain it to others and stress that the aim is that we all need to get to know each other' (R14, also 5, 16), which shows a strategy of incrementalism.

Finally, citizen co-producers follow coping strategies leading to the realization of both conflicting public values. 'Building firewalls' was found to be followed when citizen coproducers needed to guard their own limits: 'I am always very clear on what they can ask me, and I clearly tell them what they should ask a professional' (R2, also 16). Citizen co-producers also hybridize certain values. Respondent 13 copes with a tension between wanting to help out others and the time she has available: 'I can't be present at the preparations, it's impossible, so I help out after, for example by doing the dishes and cleaning the tables' (R13).

\subsubsection{Steering committee}

The members of the steering committee prove not very different from the citizen co-producers in applying coping strategies. They build firewalls in order to guard their limits (R7) and tend to hybridize conflicting values (R5). The one difference may to be explained by their position: rather than avoiding value conflicts, they escalate them to their own steering committee, where they can decide how to cope with the issue $(\mathrm{R} 4,7,8)$. However, an argument for escalating to the project coordinators rather than dealing with an issue in the committee is that they 'think that people will accept their decisions more' (R7) if they do so. Like the project coordinators, members of the steering committee bias those values which correspond with the ideals of the project. As a respondent states on the issue of the seating arrangements during the meetings: 'if you do not talk to other people, you won't get to know them. And this is important to do because of the aim of Connected Care: getting to know different people' (R8). They choose a strategy of incrementalism if they want to give preference to one value, for example, by explaining the reason for the seating to the other citizen co-producers and by organizing more activities through which social capital is created: 'I think we have to go deeper into explaining why we choose to [have fixed seating arrangements] by showing them their shyness prevents them from fulfilling their needs' (R4).

\section{DISCUSSION AND CONCLUSION}

In order to answer our research question: to what extent does co-production in social care either enhance or obstruct the realization of public values?, we studied the individual experiences of project coordinators and citizens involved in the co-production of informal care for elderly in a small Flemish municipality.

In their search to uphold values co-producers experience value tensions; coping with these tensions may stimulate the realization of certain values, but may at the same time obstruct other values. Having studied actors involved in one specific case of social care, we acknowledge that the specific 
examples on expectations, value tensions and coping strategies presented in the results cannot be generalized to other cases and other sectors. Case studies offer the advantage of studying a phenomenon within its context, but do not allow for statistical generalization (Eisenhaerdt and Graebner 2007). Practical issues such as a person's health and abilities, having to work together with different people, a high demand put on individuals, demand shyness (i.e., the reluctance to ask for aid) and non-take up resulting from this, and non-appreciation - they all limit citizen coproducers in creating private or public value within this specific case of social care co-produced for and by vulnerable elderly. Future research, however, should make it possible to compare value tensions and coping strategies in a variety of cases from different policy sectors.

Nevertheless, the study shows the potential of co-production for realizing public values. Our exploratory case study shows that the claim (e.g., Ross et al. 2013) that co-production would balance out certain value tensions for regular producers, such as the tension between efficiency and effectiveness, may not be made. Co-producers experience not only value tensions typical of the public sector, such as that between efficiency and effectiveness, but also new tensions that have to do with their role as enablers of co-production and with their interaction with service users as co-producers (or the collaborative process): tensions between inclusion and efficiency or between individual freedom and effectiveness. Additionally, we identified the potential of co-production for realizing values which may not be upheld through regular production of services, e.g., increased responsiveness to the needs of the service users.

We clustered public values in three categories, referring to service delivery, relationships between citizens and public servants, and democratic quality of the service delivery process. We found that tensions arose both within and between categories, and were different for the citizen co-producers, the project coordinators, and the members of the steering committee. In our case study the values found to be most conflicting for the project coordinators are those that can be linked to their role as enablers of co-production (such as individual freedom, important for the participation of the citizen co-producers), and to their role as public managers (such as efficiency, which is important when the budget is limited). As a civil servant, the project coordinator has responsibilities that go beyond providing outputs; society holds her accountable for public service delivery, but she is also aware of the managerial constraints in implementing the project. The members of the steering committee experience value conflicts similar to those that confront the project coordinators, which may be explained by their coordinating role and their perception of holding responsibility. The citizens who have taken on a more active and responsible role experience different tensions from those confronting the citizen co-producers who are not on the steering committee. Thus, studying the value tensions separately for each actor group was found to be relevant: taking up a different role in the co-production process may influence the value tensions experienced. Therefore, we suggest that future research should look more deeply into the effects of the role perceptions of different actors on the values treasured and the coping strategies followed.

It is not self-evident that co-production should provide a solution for dealing with public value tensions. The way actors cope with value tensions is decisive for the realization of public values, since some coping strategies still allow for two conflicting values to be upheld at the same time, whereas other coping strategies limit the realization to just one value, thereby deconstructing the other. In our case the project coordinators adhered to all coping strategies identified in the literature when dealing with value tensions. They bias values (through biasing, casuistry, or incrementalism) 
and combine this with building firewalls, i.e., they allow the 'fallen' values to be realized in separate activities. Additionally, due to lack of time they defer coping, i.e., they mention a desired coping strategy but do not yet follow up on it. Likewise, citizen co-producers follow various coping strategies, but mostly choose an escalation strategy (moving up responsibility to the project coordinators) or an avoidance strategy (not dealing with the conflict at all). This suggests that the accountability for upholding public values stays with the professionals involved in the coproduction. Furthermore, this may point to the lack of 'voice' and capacities citizen co-producers have in dealing with value tensions (cf. Lehoux et al. 2012).

\section{ACKNOWLEDGEMENTS}

We would like to thank all actors involved in "Connected Care" for participating in this study.

\section{BIBLIOGRAPHY}

Alford, J. 2002. "Why do public-sector clients coproduce? Toward a Contingency Theory." Administration \& Society, 34(1), 32-56.

Alford, J. 2009. Engaging Public Sector Clients: From Service-Delivery to Co-Production. Basingtoke: Palgrave McMillan.

Alford, J. 2014. "The Multiple Facets of Co-Production: Building on the work of Elinor Ostrom." Public Management Review 16 (3), 299-316.

Alford, J. 2016. "Co-Production, Interdependence and Publicness: Extending public servicedominant logic." Public Management Review 18 (5), 673-691.

Alford, J., and Yates, S. 2015. "Co-Production of Public Services in Australia: The Roles of Government Organisations and Co-Producers." Australian Journal of Public Administration, 75 (2), 159-175.

Amery, J. 2014. Co-creating in health practice. UK: Radcliffe.

Batalden, M., Batalden, P., Margolis, P., Seid, M., Armstrong, G., Opipari-Arrigan, L., and Hartung, H. 2015. "Coproduction of healthcare service." BMJ Qual Saf Published Online First: 16 September 2015, doi:10.1136/bmjqs-2015-004315, 1-9.

Beck Jørgensen, T. 2006. "Public Values, Their Nature, Stability and Change: The Case of Denmark." Public Administration Quarterly, 30 (3), 365-398.

Beck Jørgensen, T., and Bozeman, B. 2007. "Public Values. An Inventory." Administration \& Society 39 (3), 354-381.

Bidani, B., Fatou Diagne, M., and Zaidi, S. (2012). "Subjective perceptions of the impact of the global economic crisis in Europe and Central Asia: the household perspective." The world bank, policy research working paper series: 5995. Washington, DC: World Bank. 
Bovaird, T. 2007. "Beyond Engagement and Participation: User and Community Coproduction of Public Services." Public Administration Review 67 (5), 846-860.

Bovens, M., 't Hart, P., and van Twist, M. 2007. Openbaar Bestuur, Beleid, organisatie en politiek [Public Governance, Policy, organisation and politics]. Alphen aan den Rijn: Kluwer.

Bozeman, B. 2007. Public values and public interest: counterbalancing economic individualism. Washington: Georgetown university press.

Braddock, C. 2010. "The emerging importance and relevance of shared decision making to clinical practice." Med Decis Making 30 (Suppl 1), 5S-7S.

Brandsen, T., and Helderman, J.-K. 2012. "The Trade-Off Between Capital and Community: The Condition for Succesful Co-production in Housing." International Journal of Voluntary and Nonprofit Organizations 23 (4), 1139-1155.

Brandsen, T, Steen, T., and Verschuere, B. 2018. Co-production and co-creation: Engaging citizens in public services. London: Routledge.

Bryson, J., Sancino, A., Benington, J., and Sorensen, E. 2017. "Towards A Multi-Actor Theory of Public Value Co-Creation." Public Management Review 19 (5), 640-654.

Buckwalter, N. D. 2014. "The Potential for Public Empowerment through GovernmentOrganized Participation." Public Administration Review 67 (1), 14-28. doi: 10.1111/puar.12217

Carman, K., Dardess, P., Maurer, M., Sofaer, S., Adams, K., Bechtel, C. and Sweeney, J. 2013. "Patient and family engagement: a framework for understanding the elements and developing interventions and policies." Health Affairs 2, 223-231.

de Graaf, G., and Paanakker, H. 2014. "Good Governance: Performance Values and Procedural Values in Conflict." American Review of Public Administration 45 (6), 118.

de Graaf, G., and Van der Wal, Z. 2010. "Managing conflicting public values: Governing with integrity and effectiveness." American Review of Public Administration 40 (6), 623-630.

de Graaf, G., Huberts, L., and Smulders, R. 2016. "Coping With Public Value Conflicts." Administration \& Society 48 (9), 1101-1127.

De Vries, H., Bekkers, V., and Tummers, L. 2015. "Innovation in the Public Sector: A Systematic Review and Future Research Agenda." Public Administration 94 (1), 146166.

Dunston, R., Lee, A., Boud, D., Brodie, P., and Chiarella, M. 2009. "Co-production and health system-from re-imaginging to re-making." Public Administration 68 (1), 3952 .

Eisenheardt, K., and Graebner, M. 2007. "Academy of Management Journal." Theory Building From Cases: Opportunities And Challenges 50 (1), 25-32.

Farr, M. 2016. "Co-Production and Value Co-Creation in Outcome-Based Contracting in Public Services." Public Management Review 18 (5), 654-672. 
Fledderus, J. 2015. User co-production of Public Service Delivery. Nijmegen: Radboud University.

Gebauer, J., Fuller, J., and Pezzei, R. 2013. "The dark and the bright side of co-creation: Triggers of member behavior in online innovation communities." Journal of Business Research 66 (9), 1516-1527. doi: 10.1016/j.jbusres.2012.09.013

Gustafsson, K., and Lidskog, R. 2012 "Acknowledging risk, trusting expertise, and coping with uncertainty: Citizens' deliberations on spraying an insect population." Society \& Natural Resources 25(6): 587-601.

Habibov, N, and Afandi, E. 2017. "Community-Level Social Capital and Household Strategies for Coping with Global Crisis in Transitional Countries". Social Indicators Research 130 (2), 687-710.

Hood, C. 1991. "A Public Management for all Seasons?" Public Administration 69 (1), 3-19.

Lipsky, M. 1980. Street-Level Bureaucracy: Dilemmas of the Individual in Public Services. New York: Russel Sage Foundation.

Loeffler, E., Power, G., Bovaird, T., and Hine-Hughes, F. 2013. Co-production of health and wellbeing in Scotland. Birmingham: Governance International.

Loyens, K., \& Maesschalck, J. 2010. "Toward a theoretical framework for ethical deision making of street-level bureaucracy: existing models reconsidered." Administration \& Society, 42 (1), 66-100.

Lukes, S. 1996. "On trade-offs between values." in Ethics, rationality and economic behaviour, edited by Farina, F.; Hahn, F.; and Vannucci S. Oxford, UK: Clarendon Press., 36-49.

Maynard-Moody, S., and Musheno, M. 2003. Cops, Teachers, Counselors: Stories from the Front Lines of Public Service. Ann Arbor: MI: University of Michigan Press.

Meijer, A. 2014. "New media and the coproduction of safety: an empirical analysis of Dutch practices." American Review of Public Administration 44 (1), 17-34.

Meijer, A. 2016. "Coproduction as a structural transformation of the public sector." International Journal of Public Sector Management 29 (6), 596-611.

Moore, M. 2014. "Public value accounting: Establishing the philosophical Basis." Public Administration Review, 74 (4), 465-477.

Needham, C., and Carr, S. 2009. SCIE Research briefing 31: co-production: an emerging evidence base for adult social care transformation. London: Social Care Institute for Excellence.

Neshkova, M. I., and Guo, H. 2012. "Public Participation and Organizational Performance: Evidence from State Agencies." Journal of Public Administration Research and Theory 22 (2), 267-288. doi: 10.1093/jopart/mur038

O'Kelly, C., and Dubnick, M. 2006. "Taking tough choices seriously: Public Administration and individual moral agency." Journal of Public Administration Research and Theory $16(3), 393-415$. 
Osborne, S. P., Radnor, Z., and Strokosch, K. 2016. "Co-production and the Co-creation of Value in Public Services: A suitable case for treatment?" Public Management Review, 18 (5), pp. 639-653.

Pestoff, V. 2006. "Citizens and co-production of welfare service: childcare in eight European countries." Public Management Review 8 (4), 503-519.

Pestoff, V., Brandsen, T., and Verschuere, B. 2013. New Public Governance, the Third Sector and Co-Production. New York: Routledge.

Ross, P., Needham, C., and Carr, S. 2013. Co-production in social: What it is and how to do it. SCIE guide 51.

Rutgers, M. 2008. "Sorting Out Public Values? On the Contingency of Value Classification in Public Administration." Administrative Theory \& Praxis 30 (1), 92-113.

Schott, C. 2015. "Playing a role - but which one? How public servic emotivation and professionalism affect decision-making in dilemma situations." $\mathrm{PhD}$ diss., Leiden University.

Schott, C., Van Kleef, D., and Steen, T. 2015. "What does it Mean and Imply to be Public Service Motivated?" American Review of Public Administration 45 (6), 689-707.

Sims, R., and Keon, T. 1999. "Determinants of Ethical Decision Making: the Relationship of the Perceived Organizational Environment." Journal of Business Ethics, 19, 393-401.

Steen, T., Brandsen T. and Verschuere, B. 2018. "The dark side of co-creation and coproduction. Seven evils." in Co-production and co-creation: Engaging citizens in public services, edited by Brandsen, T.; Steen, T. and Verschuere, B. London: Routledge.

Steen, T., and Tuurnas, S. 2018. "The roles of the professional in the co-production process." in Co-production and co-creation: Engaging citizens in public services, edited by Brandsen, T.; Steen, T. and Verschuere, B. London: Routledge.

Steenhuisen, B. 2009. Competing Public Values: Coping strategies in heavily regulated utility industries. Delft: Technische Universiteit Delft.

Steenhuisen, B, and van Eeten, M. 2012. "Patterns of Coping With Inconsistent Demands in Public Service Delivery." Administration \& Society, 45 (9), 1130-1157.

Stewart, J. 2006. "Value conflict and policy change." Review of Policy Research 23 (1), 147152.

Strauss, A., and Corbin, J. 2008. Basics of qualitative research: grounded theory procedures and techniques (2nd ed.). Thousand Oaks: CA: Sage.

Szreter, S. and Woolcock, M. 2004. "Health by association? Social capital, social theory, and the political economy of public health." International Journal of Epidemiology, 33, (4), 650-667.

Tetlock, P. 2000. "Coping with trade-offs: psychological constraints and political implications." in Elements of reason. Cognition, choice and the bounds of rationality, edited by Lupia, A.; McCubbins, M., and Popkin, S.. Cambridge: Cambridge University Press. 
Thacher, D., and Rein, R. 2004. "Managing value conflict in public policy." Governance 17 (4), 457-486.

Thomsen, M., and Jakobsen, M. 2015. "Influencing citizen coproduction by sending encouragement and advice: a field experiment." International Public Management Journal 18 (2), 286-303.

Tummers, L., Bekkers, V., Vink, E., Musheno, M. 2015. "Coping During Public Service Delivery: A Conceptualization and Systematic Review of the Literature." JPART, 25 (4), 1099-1126.

van Eijk, C. 2017. "Engagement of Citizens and Public professionals in the co-production of public services." PhD diss., Leiden University.

Van Eijk, C., \& Steen, T. 2014. "Why People Co-Produce: Analysing citizens' perceptions on co-planning engagement in health care services." Public Management Review, 358382.

van der Wal, Z., de Graaf, G., and Lawton, A. 2011. "Competing Values in Public Management." Public Management Review 13 (3), 331-341.

van Gestel, I., Koppenjan, J., Schrijver, I., van de Ven, A., and Veeneman, W. 2008. Managing Pubilc Values in Public-Private Networks: A Comparative Study of Innovative Public Infrastructure Projects. Public Money and Management 28 (3), 139-145.

Vanleene, D., Verschuere, B., and Voets, J. 2015. "Co-producing a nicer neighbourhood: why do people participate in community development projects?" Paper presented at the IIAS Conference on co-production of public services, Nijmegen, June.

Vanleene, D., Voets, J., and Verschuere, B. 2017. "Co-producing a Nicer Neighbourhood: Why do People Participate in Local Community Development Projects?" Lex Localis, 15 (1), 111-132.

Verschuere, B., Brandsen, T., and Pestoff, V. 2012. "Co-production: The State of the Art in Research and the Future Agenda." International Journal of Voluntary and Nonprofit Organizations 23 (4), 1083-1101.

Wherton, J., Surgarhood, P., Procter, R., Hinder, S. and Greenhalgh, T. 2015. "Co-production in practice: how people with assisted living needs can help design and evolve technologies and services." Implementation Science, 1-10.

Williams, B., Kang, S.-C., \& Johnson, J. 2016. "(Co)-Contamination as the Dark Side of CoProduction: Public value failures in co-production processes." Public Management Review, 18 (5), 692-717.

Witesman, E. 2016. "From Public Values to Public Value and Back Again." Working paper prepared for the Public Values Workship hosted by the Center for Organization Research and Design (p. 35). Arizona State University: January 7-8 2016.

World Health Organization. 2016. "WHO global strategy on people-centred and integrated health services." Interim Report.

XXXX. 2018 


\section{APPENDICES}

Table A. Respondents

\begin{tabular}{l|l|l|l}
\hline \hline Respondents & Sex & Co-producer & $\begin{array}{l}\text { Coordinating } \\
\text { committee }\end{array}$ \\
\hline \hline 1 & Female & Citizen co-producer & No \\
\hline 2 & Male & Citizen co-producer & No \\
\hline 3 & Male & Citizen co-producer & No \\
\hline 4 & Female & Citizen co-producer & Yes \\
\hline 5 & Female & Citizen co-producer & No \\
\hline 6 & Female & Citizen co-producer & No \\
\hline 7 & Male & Citizen co-producer & Yes \\
\hline 8 & Female & Citizen co-producer & Yes \\
\hline 9 & Female & Public professional & Yes \\
\hline 10 & Female & Volunteer & Yes \\
\hline 11 & Female & Citizen co-producer & Yes \\
\hline 13 & Male & Citizen co-producer & No \\
\hline 14 & Female & Citizen co-producer & No \\
\hline 15 & Female & Citizen co-producer & No \\
\hline 16 & Female & Citizen co-producer & No \\
\hline & Female & Citizen co-producer & No \\
\hline
\end{tabular}

Table B. Characteristics of the Respondents ( $N=17)$

\begin{tabular}{ll}
\hline Age & N \\
35 and $<45$ & 0 \\
45 and $<55$ & 2 \\
55 and $<65$ & 6 \\
65 and $<75$ & 1 \\
75 and $<85$ & 5 \\
85 and $<95$ & 1 \\
95 and $<105$ & 1 \\
Missing & 1 \\
\hline Gender & 4 \\
Male & 13 \\
Female & 12 \\
Intensity of participation & \multicolumn{2}{c}{4} \\
High & 2 \\
$\quad$ Of which member of the steering committee & 5 \\
Low which volunteer and public servant &
\end{tabular}




\section{TABLES}

Table 1. Population of the Connected Care case

\begin{tabular}{l|l|l|l|l|l}
\hline \hline & $\begin{array}{l}\text { \# public } \\
\text { servants }\end{array}$ & $\begin{array}{l}\text { volunteers } \\
\text { producers }\end{array}$ & $\begin{array}{l}\text { \# citizen co- } \\
\text { producers } \\
\text { taking part in } \\
\text { board } \\
\text { meetings }\end{array}$ & total \\
\hline \hline Total & 1 & 1 & 76 & 4 & 82 \\
\hline Respondents & $1(100 \%)$ & $1(100 \%)$ & $\begin{array}{l}11 \\
(/ 76=18.8 \%)\end{array}$ & $4(100 \%)$ & 17 \\
\hline $\begin{array}{l}\text { Respondents } \\
\text { Female }\end{array}$ & 1 & 1 & $\begin{array}{l}8(/ 64= \\
12.5 \%)\end{array}$ & $3(100 \%)$ & 13 \\
\hline $\begin{array}{l}\text { Respondents } \\
\text { Male }\end{array}$ & 0 & 0 & $3(/ 12=25 \%)$ & $1(100 \%)$ & 4 \\
\hline
\end{tabular}




\section{Table 2. Codes and subcodes for the interview analysis}

Public values

- Better services
$\circ \quad$ Efficiency
- Effectiveness
○ Quality
- Satisfaction
○ Sustainability

- $\quad$ Better relationship

$\circ \quad$ Learning

○ Trust

- Being considerate of client's needs: accountable, responsive and transparent

- Being considerate of clients' capacities

○ Reciprocity

- Individual freedom

- Better democratic quality
○ Participation
- Empowerment
- Inclusion
- Social Capital

Tensions*

- Better services

- Better relationship

- Better democratic quality

Coping strategies

- Bias

- Building firewalls

- Cycling

- Casuistry

- Hybridization

- Incrementalism

- Escalation

- $\quad$ Avoidance/Drop-out

- $\quad$ Deferred coping

Actors

Public servant

- Volunteer

- Citizen co-producer

- $\quad$ Steering Committee

*same subcodes as for 'expectations public values' 